\title{
GOVERNMENT EXPENDITURE ON SCIENTIFIC RESEARCH, 1963
}

\begin{abstract}
WHE report of the Council for Scientific and Industrial Research for the year 1963 * records gross expenditure during the year ended December 31,1963 , of $£ 19,479,540$, compared with $£ 16,691,172$ in the year ended March 31 , 1962. The 1963 figure is reduced to $£ 17,231,547$ by various receipts from industry and other sources for services rendered, of which $£ 960,142$ was from other Government departments and $£ 977,482$ from industry$£ 224,085$ being received by the National Physical Laboratory. The net increase on 1962 was $£ 2,853,345$, while staff rose from 6,525 to 6,723 during the ealendar year. Grants for special researches again ros $\ni$, to $£ 3,297,186$ compared with $£ 2,275,060$ in 1962 , contributions to the European Organization for Nuclear Research from $£ 1,359,000$ to $£ 1,700,000$, and receipts of $£ 116,196$ reduced the subseriptions to the North Atlantic Treaty Organization and Organization for European Economic Co-operation scientific schemes to $£ 76,436$. There is a now item of $£ 28,827$ for United Kingdom Space Research Management Services.
\end{abstract}

Postgraduate training awards amounted to $£ 1,735,067$ $(£ 1,289,903$ in 1962), and the 1,958 new studentships, an increase of 22 per cent, brought the total current at the end of the year to 4,036 . While the value of research fellowships was increased by $£ 100$, only 78 new awards wero made, compared with 92 in 1962 , bringing the total current to 147. Besides 38 studentships and 18 fellowships awarded for study abroad (24 and 28 , respectively, in 1962), 20 fellowships and 1 studentship were awarded to assist British scientists and engineers to return from North America. Of the 3,469 current research studentships, 461 were in biology and biological chemistry, 264 in chemical engineering and metallurgy, 979 in chemistry, 161 in electrical and 291 in other fields of engineering, 238 in geology, 76 in the human sciences, 296 in mathematics and 703 in physics. The advanced course studentships were distributed mainly in mathematics (115), physics (91) and engineering, other than electrical (85), with 47 in the human sciences, 44 in chemical engineering and metallurgy, 36 in electrical engineering, 26 in geology, 25 in biology and biochemistry, and 21 in chemistry. All 77 first-year studentships were again in chemistry, and of the 147 rescarch fellowships, 55 were in chemistry, 40 in physics, 25 in biology and biochemistry, and 10 in geology.

Grants for special researches totalled 929, 587 being new, and of the 929 totalling $£ 11,813,668$ in value in the year ended March $31,1963,194$ (valued at $£ 1,308,893$ ) were in chemistry; $149(£ 1,334,205)$ in technology; 147 $(£ 947,245)$ in biology; $115(£ 955,525)$ in physics; 72 $(£ 601,677)$ in geology; $66(£ 466,881)$ in the human sciences; $64(£ 645,358)$ in metallurgy and materials; 51 $(£ 3,008,060)$ in nuclear physics; $33(£ 596,668)$ in space research; $19(£ 1,073,275)$ in astronomy; $9(£ 47,311)$ in mathematics; fivo each in documentation and in reactors totalled $£ 50,850$ and $£ 777,720$, rospectively. During the academic year 1962-63, tho Research Grants Committee considered 639 now applications for grants with a total

* Department of Scientific and Industrial Rescarch. Report of the H.M.S.O., 1964.) 4s. $6 d$. net. (See also p. 997 of this issue of Nature.) value of $£ 6,318,000$, compared with 487 valued at $£ 4,147,000$ in the previous year, and made 513 grants with a total value of $£ 3,596,000$ (excluding grants of $£ 100,000$ for maintaining existing capital projects, compared with 390 amounting to $£ 2,313,000$ in the previous year. The Human Sciences Committeo made 31 awards amounting to $£ 150,000$. In addition, a grant of $£ 1 \cdot 1$ million was approved for the construction and operation of a $100-\mathrm{MeV}$ electron linear accelerator to enable Prof. P. I. Dee to carry out an extensive programmo of investigation into photo-problems in nuclear physics (the accelerator is being built in the grounds of the National Engineering Laboratory, East Kilbride). A further grant of $£ 139,000$ was made to the University of Manchester to enable Sir Bernard Lovell to make a survey of the angular diameter of radio stars. A grant of $£ 121,500$ was made for Prof. N. J. Petch's work at the University of Newcastle upon Tyne on the development of materials with improved resistance to brittle fracture; smaller grants for work in this ficld, totalling $£ 126,082$, were allocated to other universities. An earmarked grant of $£ 15,300$ was offered to the British Welding Association, $£ 100,000$ for staff and running costs until 1967 for fundamental research in biosynthetic mechanisms under Prof. E. B. Chain at the Imperial College of Science and Technology, and $£ 142,000$ to the University of Southampton to assist the establishment of an Institute of Sound and Vibration Research under Prof. E. J. Richards.

With the exception of fire research and hydraulies research, in which net expenditure decreased slightly, from $£ 57,056$ to $£ 39,668$ and from $£ 118,152$ to $£ 105,489$, respectively, expenditure on all branches of the Department's work increased during the year, and in these two fields roceipts amounting to $£ 130,937$ and $£ 161,379$ (both up in 1962) accounted for more than half the gross expenditure. Likewise, a decrease in the net expenditure of the National Lending Library for Science and Technology from $£ 258,922$ to $£ 248,024$ is accounted for by an increase in receipts from $£ 45,327$ to $£ 87,803$. While receipts of $£ 399,472$ in the previous year gave expenditure on the Tropical Products Institute a credit balancs of $£ 169,721$, this year they fell to $£ 212,965$, leaving the net expenditure at $£ 17,472$. There is a new item of $£ 53,215$ net on development contracts. The major increases in expenditure during the year are the National Physical Laboratory (£2,164,502 gross; £2,033,109 in 1961-62); road research $(£ 1,086,674 ; £ 970,403)$; the Warren Spring Laboratory ( $£ 538,554 ; £ 471,181)$; the National Engineering Laboratory (£1,006,609; £924,978); building research $(£ 858,271 ; £ 781,037)$; radio research $(£ 379,041$; $£ 320,163)$; and the National Chemical Laboratory $(£ 431,416 ; £ 409,887)$. For forest products research the corresponding figures are $£ 216,682$ and $£ 194,619$; Geological Survey and Museums, $£ 649,807$ and $£ 578,919$; Laboratory of the Government Chemist, $£ 524,375$ and $£ 491,215$; Torry Research Station, $£ 252,709$ and $£ 226,696$; water pollution research, $£ 199,932$ and $£ 183,550$. Exponditure on headquarters administration increased from $£ 615,536$ to $£ 678,775$, annual grants to research associations from $£ 2,005,453$ to $£ 2,073,565$, and special assistance to industry from $£ 59,675$ to $£ 81,209$. 